\title{
CSF IN 85 PATIENTS WITH AIDS AND CNS CRYPTOCOCCOSIS
}

\author{
J. A. LIVRAMENTO * - L. R. MACHADO * - J. P. S. NÓBREGA * - H. R. GOMES ** \\ L. S. VIANNA ** - A. SPINA-FRANCGA ***
}

\begin{abstract}
SUMMARY - In an eight years time period (July 1984-June 1992) CSF samples of 40718 patients were studied, and 610 were from patients with AIDS clinically diagnosed and immunologically confirmed through HIV antibodies detection. Among opportunistic infections detected in them 85 were CNS cryptococcosis. For the purpose of this study the CSF of these 85 patients are the AIDS group of CNS cryptococcosis. For comparison, CSF data from 50 patients with CNS cryptococcosis but without AIDS were taken (non-AIDS group); in this group, 22 patients were immunosuppressed after renal transplant. In AIDS group, the more frequent CSF findings were: yeast presence at direct exam (Fuchs-Rosenthal cell counting chamber), growing of the yeast in cultures, and gamma globulins increase. In non-AIDS group were more frequent: hypereytosis, neutrophil cells presence, and total protein increase. Differences between the two groups are discussed taking into account CNS/CSF immune changes induced by HIV infection. It is concluded that in CNS cryptococcosis of patients with AIDS the CSF evidenced more extensive signs of the fungal opportunistic infection than signs of inflammatory response to the infection. The latter were more prominent among patients of the non-AIDS group of CNS cryptococcosis.
\end{abstract}

KEY WORDS: cryptococcosis, central nervous system, cerebrospinal fluid, AIDS.

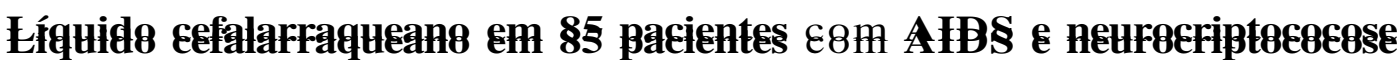

RESUMO - Foi estudado o LCR de 85 pacientes com AIDS e criptococose do SNC. O diagnóstico clínico e imunológico de AIDS foi previamente estabelecido em todos os casos. Os resultados foram comparados aos de grupo de 50 ptaciestes com neurocriptococose porém sem AIDS (grupo não-AIDS). Neste grupo 22 pacientes eram imunossuprimidosi após transplante renal. Nos pacientes do grupo AIDS predominavam no LCR: detecção da levedura no exame direto (câmara de Fuchs-Rosenthal de contagem de células), culturas da levedura positivas e aumento do teor de globulinas gama. No grupo não-AIDS predominavam: pleoeitose, presença de polinucleares neutrófilos e aumento da concentração proteica total. As diferenças encontradas entre os dois grupos são discutidas, salientando-se as modificações imunes induzidas no SNC/LCR pelo HIV. Conclui-se quej na neurocriptococose em pacientes com AIDS o LCR evidenciou mais a infecção pelo fungo que a resposta inflamatória à infecção. Esta última predominou no LCR de pacientes do grupo neurocriptococose não-AIDS. (SIDA).

PALAVRAS-CHAVE: criptococose, sistema nervoso central, líquido cefalorraqueano, AIDS

Cryptococcosis is the most common fungal infection of the central nervous system (CNS) and the second opportunistic disease observed in AIDS patients 5-7,10. However, systematic studies on cerebrospinal fluid (CSF) of CNS cryptococcosis in AIDS are scarce as well as in othetf immunosuppressive conditions 9. For this season the present study was scheduled. It was carried out

CIN (Neurology Investigation Center, Department of Neurology, Faculty of Medicine, São Paulo University) / LSF (Neurodiagnostics Laboratory): * Assistant Professor; ** Researcher Neurologist; *** Emeritus Professor. Ptart of this investigation was presented at the International Quincke Symposium (Gõttingen, September 18-21, 1991) and at the Quincke Symposium (Lisboa, November 29-30, 1991).

Dr. José Antonio Livramento - Caixa Postal 5199 - $01061-970$ São Paulo SP - Brasil. 
in a neurodiagnostic laboratory for CSF. In an eight years time period, from July 1984 to June 1992, CSF samples of 40718 new patients were studied, and 610 were from patients with AIDS. Number of AIDS patients is $1.50 \%$ of total new cases examined hi this period 6,7. CNS cryptococcosis was diagnosed through the CSF exam in 85 of the total 610 AIDS cases $(13.9 \%), 22$ of them presenting association with other CNS infections.

The aim of this study is the comparison of CSF findings at the occasion of the diagnosis of the CNS cryptococcosis in these 85 patients with AIDS to another group of 50 patients with CNS cryptococcosis but without AIDS.

\section{CASUISTICS AND METHOD}

Clinical and immunological screening for AIDS was previously performed in all 85 cases. All AIDS patients had HIV antibodies in serum; in CSF HIV antibodies testing was carried at 64 cases, and $60(93,7 \%)$ tested positive. The 85 patients with AIDS and CNS cryptococcosis (AIDS group) included: 80 male and 5 female; 77 white, 7 negro and 1 yellow; their mean age was 33 years old (range 11 to 59 years old). Thé 50 patients with CNS cryptococcosis without AIDS (non-AIDS group) included: 29 male and 21 female; 45 white, 3 yellow and 2 negro; their mean age was 42 years old (range 9 to 79 years old). In this non-AIDS group 30 patients had risk factors for cryptococcus infection: 22 renal transplant, 4 neoplasia, 1 pregnancy, 1 cardiac surgery, 1 corticotherapy and 1 lupus erythematosus.

CSF analysis included: opening pressure; cytology (cell number in the Fuchs-Rosenthal cell counting chamber, and cytomorphology in sedimentation chamber or cyto-centrifugation préparâtes); total protein content and protein profile; glucosis concentration; immunological tests for cysticercosis, syphilis, toxoplasmosis, virus infections (cytomegalovirus, varicellazoster, herpes simplex 1) and fungal infections (aspergillosis, histoplasmosis, South American blastomycosis, and candidiasis); bacteriological and mycologieal investigations (direct and cultures); cryptococcus antigen latex agglutination test. All CSF samples were analysed in the same laboratory through the same methodology<5,7. In a few cases from the non-AIDS group the CSF sediment was injected in immunossuppressed mice as described before 8 .

For the comparison between the two groups CSF data considered were: (1) opening pressure, number of cells, total protein content, gamma globulins (\%) and glucose content; (2) cytomorphologic profile; (3) mycologie diagnosis through direct exam of the sample (presence of the yeast in the CSF at Fuchs-Rosenthal cell counting chamber and at China ink preparations), antigen latex agglutination test and culture growing of the yeast (Sabouraud medium); (4) association with other pathologies.

Differences found between the two groups were tested by chi-square test; significance was p<0.05. In the AIDS group data for comparison were those of patients (63) with cryptococcosis but without associated infections (Table 1).

\section{RESULTS}

Results for general CSF data (\%) are illustrated in Figure 1, and those for mycologie diagnosis (\%) in Figure 2. Association with other infections occurred only in the AIDS group (Table 1).

Predominance of lymphocytes and monocytes in the cytomorphologic profile of CSF occurred in both groups (97\% AIDS x 90\% non-AIDS). Predominance of neutrophil cells occurred in 3\% for the AIDS group and, in 10\% for the non-AIDS group. Presence of neutrophils cells occurred in both groups (63\% AIDS x $86 \%$ non-AIDS) as well presence of eosinophil cells $(17 \%$ AIDS x $10 \%$ non-AIDS).

Normal CSF composition (normal cell number, normal protein content, normal glucose concentration) was more frequent in the AIDS group (29.2\%) than in the non-AIDS group (2.0\%). Comparing CSF data on CNS cryptococcosis in the AIDS group to the non-AIDS group by the chi-square test, differences were found to be significant for: (1) hypercytosis $(p=0.002) ;(2)$ neutrophil cells number $(p=0.009) ;(3)$ total proteins content $(p=0.03) ;(4)$ gamma globulins content $(\mathrm{p}=0.001)$; (5) presence of the yeast at the Fuchs-Rosenthal chamber exam $(p=0.03) ;(6)$ and yeast growing in cultures $(p=0.001)$. Differences (4), (5) and (6) favour the AIDS group of CNS cryptococcosis cases.

Cryptococcus neoformans shown in Figure 3 are at: Fuchs-Rosenthal cell counting chamber, China ink preparations, cell sedimentation chamber or after cyto-centrifugation préparâtes, and in a mouse brain after inoculation. 


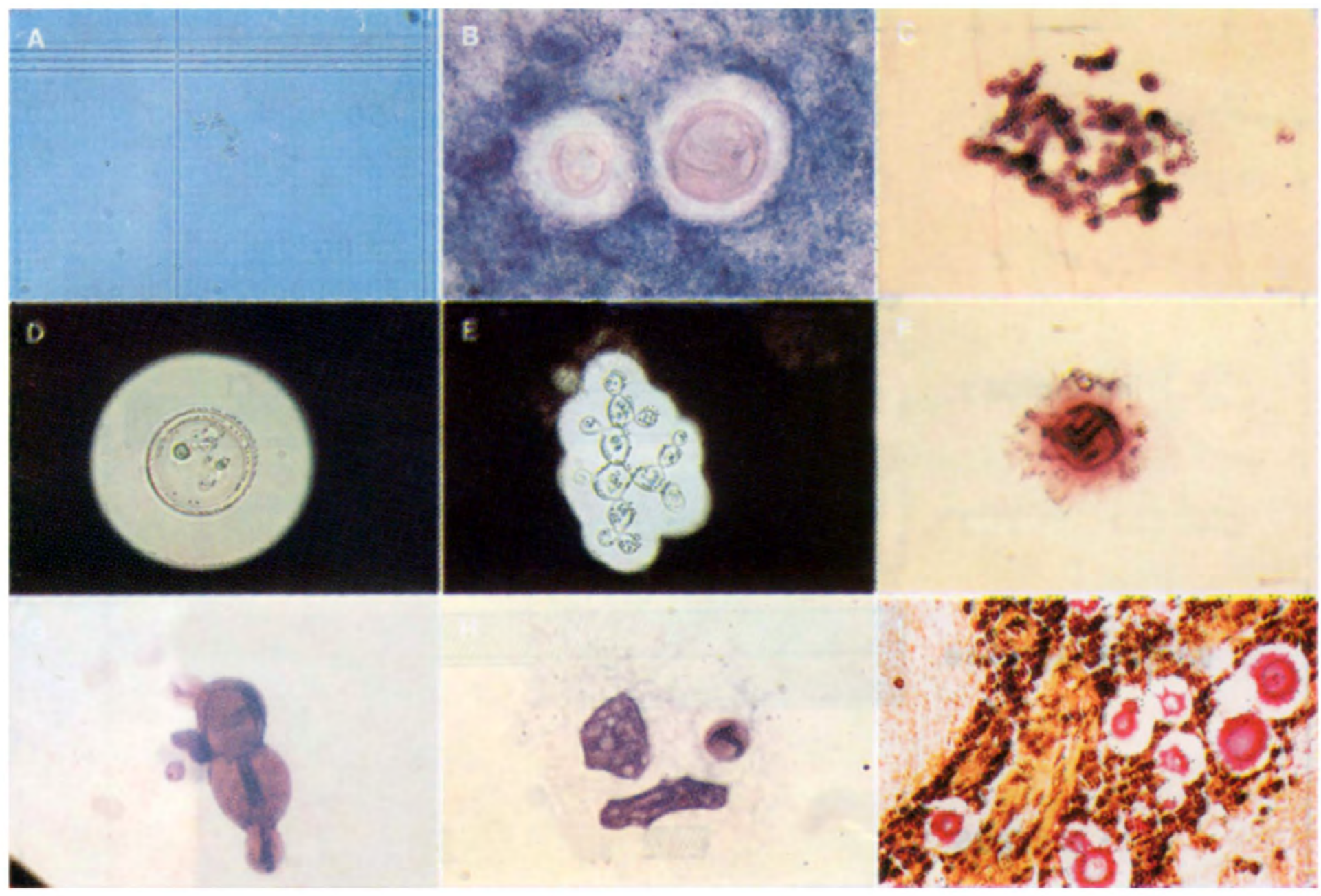

Fiy. 3. Cryptococcus neoformans in CSF (A-H) and in mouse brain (I). A, Fuchs-Rosenthal cell counting chamber, methylene blue; B, fibrin clot, May Grunwald-Giemsa stain; C, cytocentrifugation, Leishman stain; $D$ and $E$, China ink; $F$, $G$ and $H$, sedimentation chamber, Leishman stain; I, mouse brain, mucicarmine stain. $\times 320$.

lable 1. Association of infections detected through CSF exam in the CNS cryptococcosis: A:DS group (85 cases).

\begin{tabular}{lc}
\hline \multicolumn{1}{c}{ CNS infection } & Number of cases \\
\hline Cryptococcosis & 63 \\
Cryptococcosis + Toxoplasmosis & 13 \\
Cryptococcosis + Syphilis & 2 \\
Cryptococcosis + CMV & 2 \\
Cryptococcosis + Herpes simplex 1 & 1 \\
Cryptococcosis + Salmonella & 1 \\
Cryptococcosis + Toxoplasmosis + Syphilis & 1 \\
Cryptococcosis + Toxoplasmosis + CMV & 1 \\
Cryptococcosis + Syphilis + CMV & 1 \\
\hline
\end{tabular}

$C M V$, cytomegalovirus infection. 


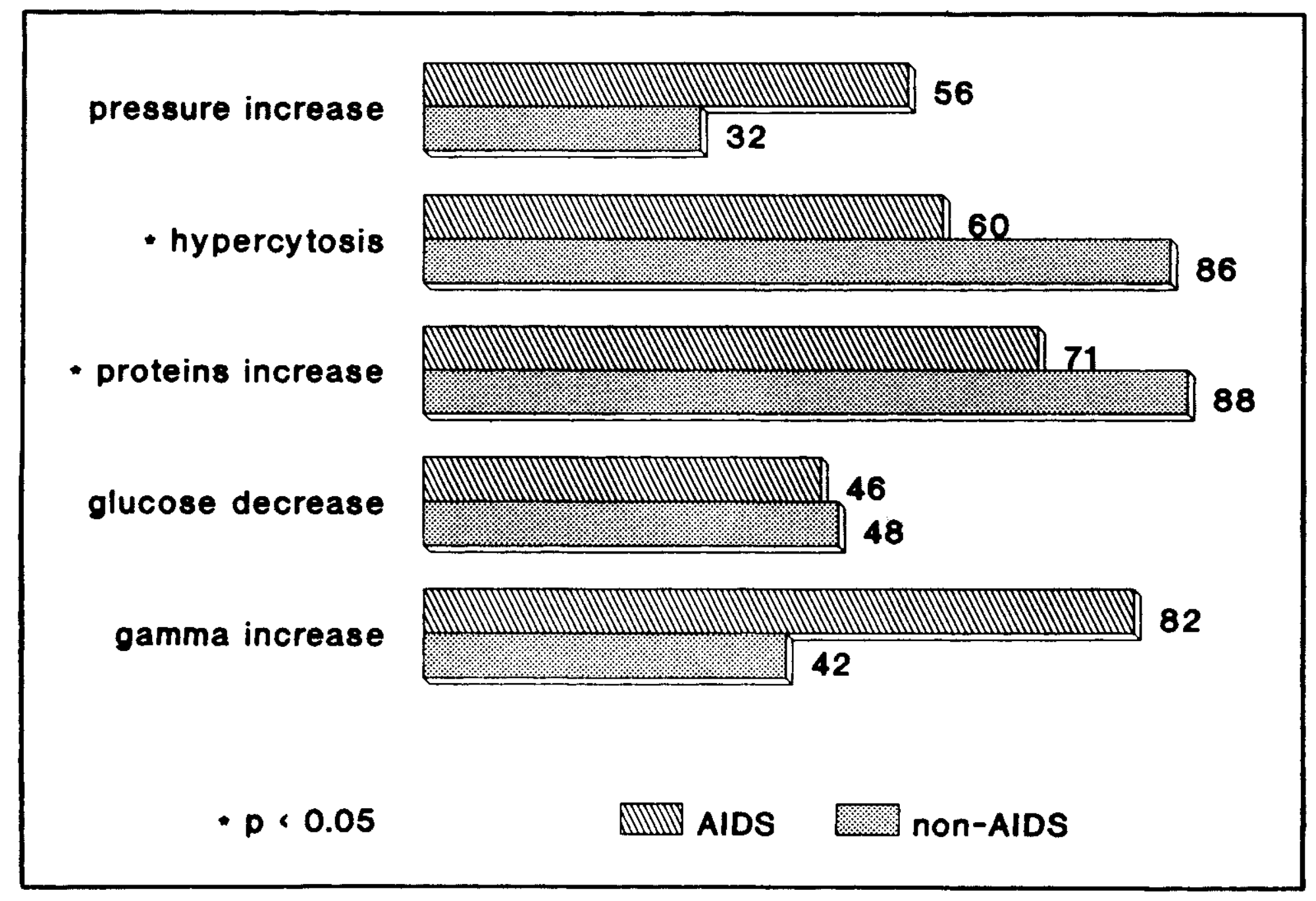

Fig. 1. General CSF datia (\%).

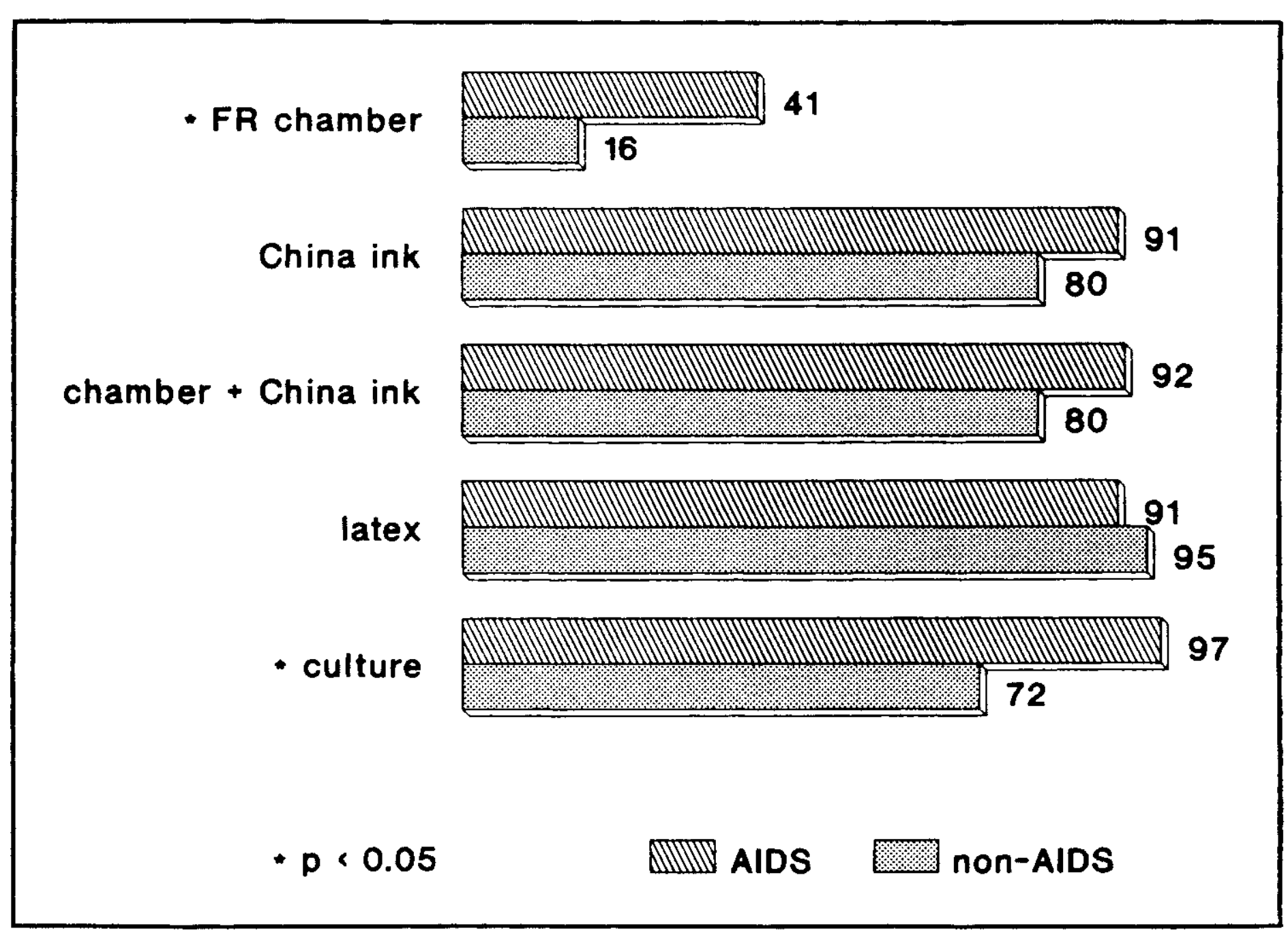

Fig. 2. Mycologic diagnosis (\%). 
Among opportunistic infections of the CNS observed in AIDS toxoplasmosis is more frequent than cryptococcosis which comes at next, according to several studies 5,Y. m this series of 610 AIDS patients the frequency of CNS cryptococcosis was $13.9 \%$. It must be emphasized that all these patients were serially followed in the same CSF neurodiagnostics laboratory in a time period of 8 years. Similar frequencies are reported for another $s t u d y^{1} *^{2}$ carried out in Sâo Paulo city $(11 \%)$ as for studies in other sites ${ }^{305}$.

Association of infections detected through CSF exam occurred in 22 patients of AIDS group and in none of the non-AIDS group. Toxoplasmosis prevailed as already reported 6,7 .

CSF syndrome in CNS cryptococcosis is a classical one and usually shows: elevated opening pressure; mild hypercytosis with presence of lymphocytes and monocytes, neutrophils, and sometimes eosinophil cells; mild increase of total protein content; and decrease of glucose concentration. In the mycologie examination the presence of the yeast on direct examination can be observed at the cell counting chamber or at China ink préparâtes or else in stained slides after sedimentation or centrifugaron. High tittles of antigen can be detected by latex agglutination. The growing of the yeast in Sabouraud medium confirms the diagnosis. The first elements of this CSF syndrome are the same observed in several subacute meningoencephalites, particularly tuberculosis of CNS.

In AIDS patients with CNS cryptococcosis this CSF syndrome may present some differences in report to the classical one above described. For this reason the main purpose of this investigation was to compare CSF data from AIDS patients with CNS cryptococcosis to those from patients not committed by AIDS who had CNS cryptococcosis, many of them immunodepressed by other causes than AIDS. Results obtained support conclusions on these differences which are discussed at next.

Similar results were observed regarding pressure, eosinophil cells presence and glucose concentration. This suggests that some general pathophysiological phenomena of subacute CNS infection are similar in both groups. They are probably related to cryptococcosis infection and virtually independent of the underlying type of immunodeficiency or the presence of HIV.

Hypercytosis, neutrophil cells and total protein increase are more frequent in non-AIDS group. In AIDS group these changes are discrete, and sometimes absent, the values found being into the reference normal range. This is probably due to differences in the blood-brain-barrier impairment between the two groups: higher in the non-AIDS group than in AIDS group. In fact, it is important to note that normal CSF profile (normal cell number, normal protein content and normal glucose concentration) occurs more frequently in the AIDS group $(\mathbf{2 9 . 2 \%})$.

Gamma globulina increase and presence of oligoclonal bands occurred more frequently in the AIDS group. This is a classical finding in patients with CNS involvement by HIV. It can be observed when concomitant fungal infection occurs as in this series. However, it may be explained by the local immune phenomena related to HIV.

Regarding the mycologie examination of CSF some data deserve mention. Rates were similar in both groups for China ink yeast detection and eryptococcus antigen detection by latex agglutination. On the other hand, yeast presence and elevated number of yeasts $/ \mathrm{mm}^{3}$ at the Fuchs-Rosenthal cell counting chamber as well as yeast growing in cultures were more frequent in the AIDS group. The growing of the yeast in Sabouraud medium at room temperature v/as faster in the AIDS group than in the non-AIDS group. In the majority of cases of AIDS group the culture was positive in the first 5 days. In the nonAIDS group, to demonstrate the presence of the yeast sometimes it was necessary to inject CSF's sediment in an experimentally immunodepressed mouse (Fig. 3-1). This can suggest that in the AIDS group fungal infection is quantitatively more expressive, possibly due to high impairment of host defense mechanisms related to fungal infection. 
Concluding, in CNS cryptococcosis of patients with AIDS the CSF evidenced more extensive signs of fungal infection than signs of inflammatory response to the infection. The latter were more prominent among patients of the non-AIDS group of CNS cryptococcosis.

Acknowledgement - The authors thank Professor Carlos da Silva Laeaz (Laboratory of Mycology, Faculty of Medicine, São Paulo University) for the kindness of his assistance throughout the years this study run, and for Figure 3-1.

\section{REFERENCES}

1. Biancalana MLN, Stefani HNV, Pasternak J, Rosenthal C, Levi GC, Mendonça JS. AIDS in São Paulo, Brasil: clinical experience with 116 hospitalized cases. In: International Congress for Infectious Diseases/Congresso da Sociedade Brasileira de Infectologia 5. Rio de Janeiro 1988, p 255 (Absitr 672).

2. Calvo B, Fishman O, Castelo A Filho, Reis J Filho, Del Bianco R, Barbosa RM, Zaror L. Detección de antígeno del polisacarido capsular de Cryptococcus neoformans en pacientes con SIDA y neurocriptococosis en São Paulo, Brasil. Rev Inst Med Trop São Paulo 1991, 33:485-490.

3. Eng RHK, Bishburg E, Smith SM. Cryptococcal infections in patients with acquired immune deficiency syndrome. Am J Med 1986, 81:19-23.

4. Kovacs JA, Kovacs AA, Polis M, Wright C, Gill VJ, Tuazon CV, Gelmann EP, Lane NC, Longfield R, Overturf G, Macher AM, Fauci AS, Parrillo JG, Bennet JE, Masur H. Cryptococcosis in the acquired immunodeficiency syndrome. Ann Intern Med 1985, 103:533-5389

5. Levy RM, Bredesen DE, Rosemblum ML. Opportunistic central nervous system pathology in patients with AIDS. Ann Neurol 1988, 23 (Suppl): S7-S12.

6. Livramento JA, Machado LR, Spina-França A. Anormalidades do líquido cefalorraqueano em 170 aasos de AIDS. Arq Neuro-Psiquiat (São Paulo) 1989, 47:326-331.

7. Livramento JA, Machado LR, Gomes HR, Vianna LS, Spina-França A. AIDS: a CSF laboratory experience on 470 cases in a seven year time period. Arq Neuro-Psiquiat (São Paulo) 1992, 50:56-59.

8. Machiado LR., Feeehio D, Limongi JCP, Berger A, Livramento JA, Spina-França A. Neurocriptococose e imunossupressão: modelo experimental em camundongos. Arq Neuro-Psiquiat (São Paulo) 1985, 43:29-38.

9. Nóbrega JPS. Anfotericina B no tratamento da neurocriptococose em pacientes submetidos a transpalnte renal. Arq Neuro-Psiquiat (Sao Paulo) 1988, 46:117-126.

10. Zuger A, Louie E, Holzmian RS, Simberkoff MS, Ráhal JJ. Cryptococcal disease in patients with the acquired immunodeficiency syndrome. Ann Intern Med 1986, 104:234-240. 